\title{
Geology
}

\section{History of Laurentide meltwater flow to the Gulf of Mexico during the last deglaciation, as revealed by reworked calcareous nannofossils}

\author{
Thomas M. Marchitto and Kuo-Yen Wei
}

Geology 1995;23;779-782

doi: 10.1130/0091-7613(1995)023<0779:HOLMFT>2.3.CO;2

\section{Email alerting services}

\section{Subscribe}

Permission request click www.gsapubs.org/cgi/alerts to receive free e-mail alerts when new articles cite this article

click www.gsapubs.org/subscriptions/ to subscribe to Geology

click http://www.geosociety.org/pubs/copyrt.htm\#gsa to contact GSA

Copyright not claimed on content prepared wholly by U.S. government employees within scope of their employment. Individual scientists are hereby granted permission, without fees or further requests to GSA, to use a single figure, a single table, and/or a brief paragraph of text in subsequent works and to make unlimited copies of items in GSA's journals for noncommercial use in classrooms to further education and science. This file may not be posted to any Web site, but authors may post the abstracts only of their articles on their own or their organization's Web site providing the posting includes a reference to the article's full citation. GSA provides this and other forums for the presentation of diverse opinions and positions by scientists worldwide, regardless of their race, citizenship, gender, religion, or political viewpoint. Opinions presented in this publication do not reflect official positions of the Society.

\section{Notes}




\title{
History of Laurentide meltwater flow to the Gulf of Mexico during the last deglaciation, as revealed by reworked calcareous nannofossils
}

\author{
Thomas M. Marchitto \\ Department of Geology and Geophysics, Woods Hole Oceanographic Institution, Woods Hole, Massachusetts 02543 \\ Kuo-Yen Wei \\ Department of Geology, National Taiwan University, Taipei, Taiwan, Republic of China
}

\begin{abstract}
The history of meltwater flow from the Laurentide Ice Sheet to the Gulf of Mexico during the last deglaciation, which holds possible implications for the cause of the Younger Dryas cold episode, is not well understood. We propose a new chronology based on using the percentage of reworked calcareous nannofossils in Orca Basin sediments as a proxy for erosion. The period of greatest meltwater flow to the gulf was between 12.7 and $12.1 \mathrm{ka}$ (during the Bølling warm interval), and flow remained high until the beginning of the Younger Dryas cold episode at $11.3 \mathrm{ka}$; this corresponds to meltwater pulse IA. A sharp meltwater decrease at $\mathbf{1 2 . 2}$ ka may represent the Older Dryas glacial readvance. Little or no meltwater is inferred to have flowed to the gulf from $\sim 10$ to $9 \mathrm{ka}$, which is the time of the second major meltwater pulse, IB. Therefore, meltwater must have been permanently diverted away from the Gulf of Mexico at the beginning of the Younger Dryas.
\end{abstract}

\section{INTRODUCTION}

Much discussion about Laurentide Ice Sheet meltwater has revolved around sediment cores in the Gulf of Mexico (Kennett and Shackleton, 1975; Emiliani et al., 1975) and especially in the Orca Basin, an anoxic depression $\sim 290 \mathrm{~km}$ southwest of the Mississippi Delta (e.g., Leventer et al., 1982, 1983; Kennett et al., 1985; Broecker et al., 1988, 1989; Flower and Kennett, 1990). High sedimentation rates, excellent microfossil preservation, lack of bioturbation, and proximity to the Mississippi River make this site ideal for highresolution meltwater studies. To elucidate the nature of meltwater flow to the gulf (Fig. 1A), Broecker et al. (1989) presented the $\delta^{18} \mathrm{O}$ record of planktonic foraminifera in the Orca Basin between $\sim 16$ and $17 \mathrm{ka}\left({ }^{14} \mathrm{C}\right.$ ages $)$. They identified a negative $\delta^{18} \mathrm{O}$ anomaly between 12.7 and $11.3 \mathrm{ka}$ as representing a large influx of fresh, isotopically negative meltwater from the decaying Laurentide Ice Sheet. This event had been previously identified in other Gulf of Mexico cores (Kennett and Shackleton, 1975; Emiliani et al., 1975, 1978; Leventer et al., 1982, 1983; Kennett et al., 1985). The shift was too large to be explained by warming alone, as its $\delta^{18} \mathrm{O}$ values were significantly more negative than those of the early Holocene (post$10.1 \mathrm{ka})$. Kennett and Shackleton (1975) and Broecker et al. (1989) attributed the sharp increase in $\delta^{18} \mathrm{O}$ at $11.3 \mathrm{ka}$ to a temporary diversion of meltwater away from the Gulf of Mexico to the St. Lawrence River. As first proposed by Rooth (1982), this diversion supposedly inhibited North Atlantic deep-water (NADW) formation and shut down the Atlantic's conveyor circulation system. The result was the Younger Dryas cold episode, which increased ocean $\delta^{18} \mathrm{O}$, making the shift in the Orca Basin core even more positive. The $\delta^{18} \mathrm{O}$ decrease at $10.1 \mathrm{ka}$ was identified as the end of the Younger Dryas, accompanied by the return of meltwater to the gulf (Broecker et al., 1989).

Fairbanks (1989) disagreed with Broecker et al.'s (1989) evidence for a meltwater diversion. He calculated a global meltwater curve from sea-level data from the reef-crest coral Acropora palmata in Barbados (Fig. 2). It shows two distinct meltwater pulses (mwp),
mwp-IA and mwp-IB, centered at $\sim 12$ and $9.5 \mathrm{ka}$, respectively. Mwp-IA, which corresponds to the prominent negative $\delta^{18} \mathrm{O}$ anomaly in the Orca Basin, began shortly after $13 \mathrm{ka}$ and reached maximum discharge at $\sim 12 \mathrm{ka}$. Discharge was at a minimum at $11 \mathrm{ka}$ and remained low until $\sim 10.5 \mathrm{ka}$, when mwp-IB began. Thus, the apparent absence of meltwater in the Gulf of Mexico during the Younger Dryas could be explained by greatly reduced melting rather than a temporary diversion. Broecker (1990) maintained that NADW formation could have been reduced by a large, brief burst of meltwater at the beginning of the diversion, before melting decreased. Broecker et al. (1990a) further proposed that a salt oscillator operated in the glacial northern Atlantic. By this mechanism, the Atlantic's conveyor circulation is primarily controlled by vapor loss and heat flux, and the meltwater diversion merely acted as a trigger to cripple an already weakened conveyor. Several authors have presented independent paleogeochemical evidence that NADW formation was decreased during the Younger Dryas (Boyle and Keigwin, 1987; Keigwin et al., 1991; Lehman and Keigwin, 1992), although others suggest that NADW formation was strong at this time (Jansen and Veum, 1990; Veum et al., 1992).

The actual history of meltwater flow to the Gulf of Mexico during the Wisconsin deglaciation is not discernible from the $\delta^{18} \mathrm{O}$ record alone, because $\delta^{18} \mathrm{O}$ reflects temperature and global ice volume as well as freshwater input. In search of another proxy for meltwater flow, we turned to sediment erosion, as evidenced by reworked calcareous nannofossils. These are mainly coccoliths, the remains of unicellular marine algae of the family Coccolithophoridae (size range $\sim 1-15 \mu \mathrm{m}$ ). Constans and Parker (1986) showed that the ratio of reworked (extinct) nannofossils to indigenous (extant) nannofossils in the Gulf of Mexico sediments is an index of erosion on a glacial-interglacial scale. During glacial lowstands of sea level, increased erosion led to greater input of Cretaceous and Tertiary coccoliths into the gulf, from continental and Mississippi Delta fan deposits. Increased meltwater flow to the Gulf of Mexico 


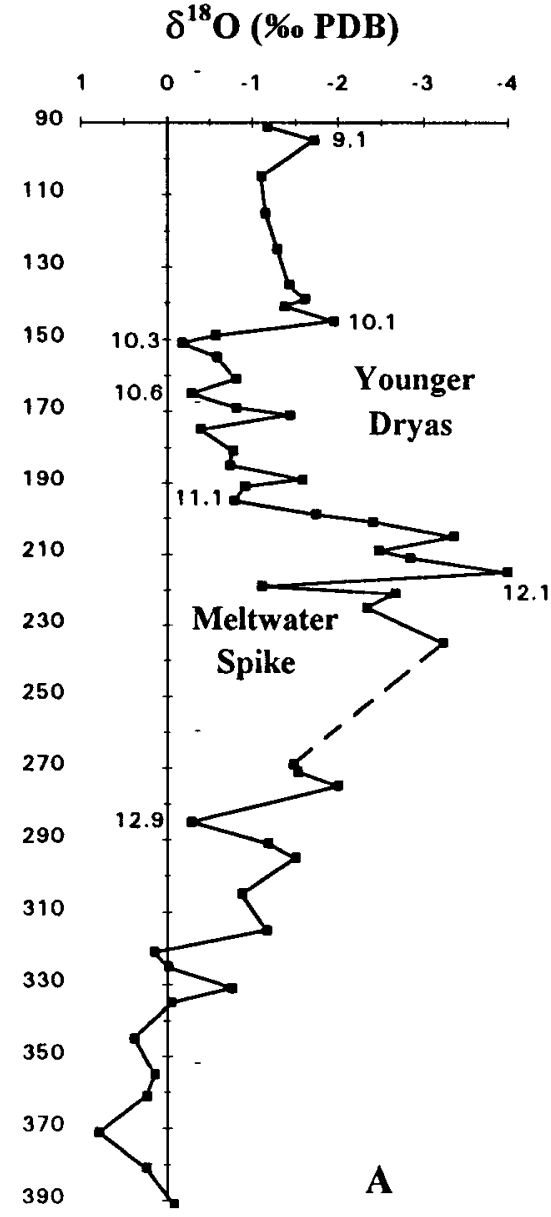

depth (cm)
Reworked (\%)

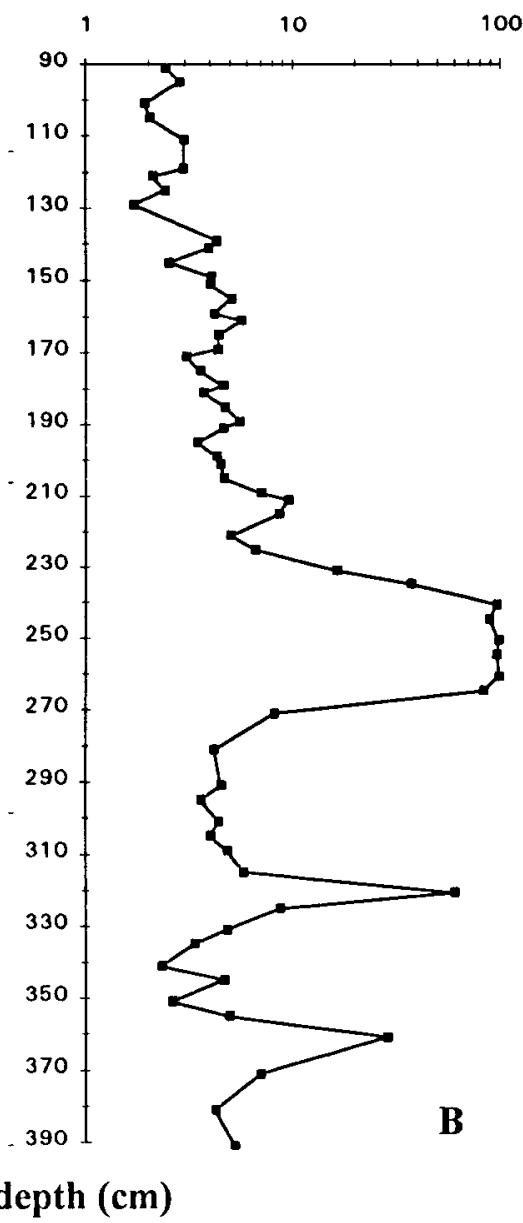

Reworked (\%)

10

100

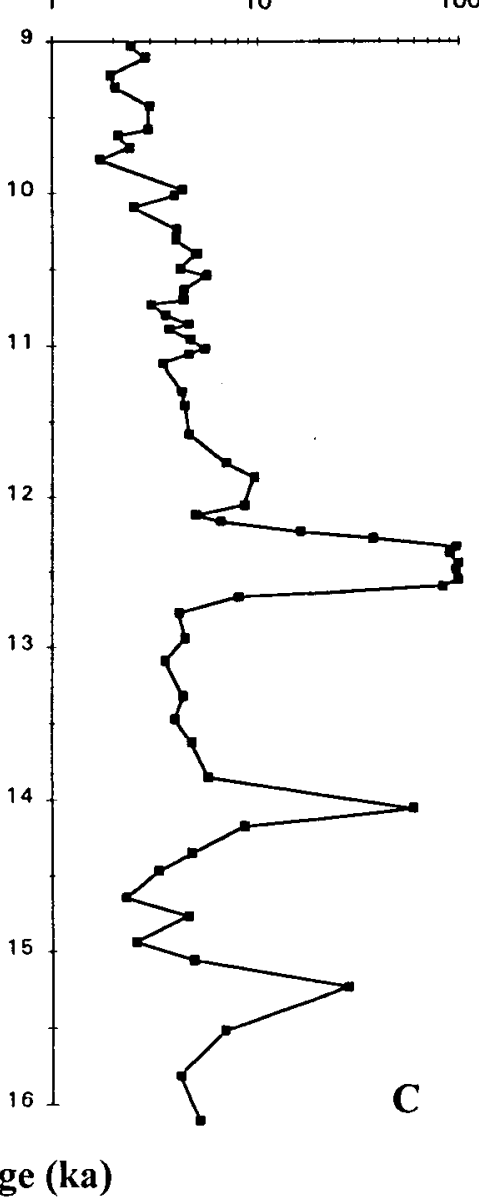

Figure 1. A: Oxygen isotope values (PDB = Peedee belemnite) for Globigerinoides ruber (white variety) from Orca Basin core EN32-PC4, plotted vs. depth (Broecker et al., 1989). Also shown are seven accelerator mass spectrometer (AMS) radiocarbon ages in ka (Broecker et al., 1989, 1990b). Prominent meltwater spike occurs between 12.7 and 11.3 ka, and Younger Dryas cold episode occurs between 11.3 and 10.1 ka. B: Percentages of reworked calcareous nannofossils for EN32-PC4, plotted on log scale vs. depth. C: Same plot as in B, but vs. age (dates revised by Flower and Kennett, 1990).

Apparent discharge rate $\left(\mathrm{km}^{3} / \mathrm{yr} \times 10^{3}\right)$

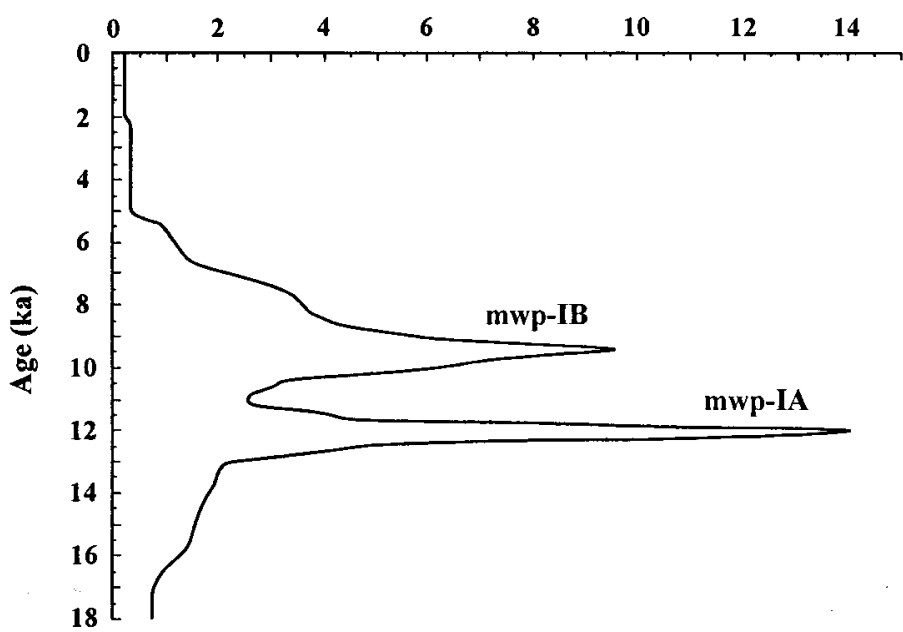

Figure 2. Global meltwater discharge rate calculated from coralderived sea-level curve, plotted vs. radiocarbon age (Fairbanks, 1989). Meltwater pulses (mwp) IA and IB are centered at 12 and $9.5 \mathrm{ka}$, respectively, and are separated by Younger Dryas cold episode. should further enhance erosion in the Mississippi watershed, increasing the input of reworked calcareous nannofossils into the gulf.

\section{METHODS}

Slides were prepared for light-microscope study from raw (unsieved) gray-brown sediment from Orca Basin piston core EN32PC4. For most of the core, two to three samples were analyzed per $10 \mathrm{~cm}$ for a total of 67 samples between 90 and $392 \mathrm{~cm}$ depth. Slides were viewed at $1250 \times$ on a Zeiss Axioscope, primarily under crosspolarized light. At least 750 nannofossils were identified (by species) and counted per sample; the only exceptions were samples in which nannofossils were scarce ( $\sim 250$ fossils counted for four samples) or rare ( $\sim 50$ counted for seven samples). For each sample, the abundance of reworked nannofossils was calculated as a percentage of total (reworked plus extant) nannofossils. Only extinct species were identified as reworked.

\section{CHRONOLOGY AND ISOTOPES}

Orca Basin core EN32-PC4 is the same core studied by Broecker et al. (1989). They obtained seven accelerator mass spectrometer (AMS) radiocarbon ages from mixed planktonic foraminifera, which were revised by Broecker et al. (1990b) (Fig. 1A). 
These ages provide an excellent chronology between 12.86 and 9.11 $\mathrm{ka}$. This chronology was extended for sediments older than $12.86 \mathrm{ka}$ by Flower and Kennett (1990), who correlated $\delta^{18} \mathrm{O}$ oscillations at 13.97 and $17.86 \mathrm{ka}$ in the planktonic foraminifer Globigerinoides ruber (white variety) with those dated by Broecker et al. (1988) in nearby core EN32-PC6. Flower and Kennett (1990) determined ages for the top of the core by extrapolating the sedimentation rate of the interval between the two youngest AMS dates. On the basis of the above chronology, the section examined in this study ranges from 16.1 (early deglacial) to $9 \mathrm{ka}$ (early Holocene).

The $\delta^{18} \mathrm{O}$ record of EN32-PC4, from the planktonic foraminifer Gs. ruber (white variety), was determined by Broecker et al. (1989) (Fig. 1A). This curve shows maximum $\delta^{18} \mathrm{O}$ values between the base of the interval and $\sim 12.7 \mathrm{ka}$, and between $\sim 11.3$ and 10.1 $\mathrm{ka}$; these correspond to the late Wisconsin glacial period and the Younger Dryas cold episode, respectively. Lower $\delta^{18} \mathrm{O}$ values occur from 12.7 to $11.3 \mathrm{ka}$ and from $10.1 \mathrm{ka}$ to the top of the section; these have been identified as a prominent meltwater spike (paired with warm, interglacial conditions) and the Holocene Epoch, respectively (Broecker et al., 1989; Flower and Kennett, 1990).

\section{RESULTS AND DISCUSSION}

Reworked nannofossils compose $<10 \%$ of total specimens for most of the core length (percentage of reworked specimens vs. depth and vs. age, Fig. 1, B and C, respectively). Three exceptions are found at $\sim 15.2,14.1$, and 12.7 to $12.2 \mathrm{ka}$. The first two peaks, each of which have only one data point above $10 \%$, do not correlate with any low $\delta^{18} \mathrm{O}$ excursions. They probably represent isolated turbidity currents associated with low sea levels, rather than major meltwater pulses. The largest peak of percentage of reworked specimens, between 12.7 and $12.2 \mathrm{ka}$, contains eight values above $10 \%$ to a maximum of $98 \%$; it corresponds well to the first half of the meltwater spike. This interval appears to be the time of maximum meltwater flow to the Gulf of Mexico and also correlates with the first half of pulse mwp-IA of Fairbanks (1989). It should also be noted that $\delta^{18} \mathrm{O}$ data are lacking from this period owing to the rarity of foraminifera; we might expect the missing values to be even lower than during the $12.1 \mathrm{ka}$ minimum.

The period between $\sim 13$ and 11 ka corresponds to the BøllingAllerød warm interval. This interval was separated by a minor glacial readvance ( 12.1-11.9 ka), the Older Dryas (e.g., Dansgaard et al., 1971; Berger, 1990). The main peak in reworked nannofossils decreases to $\sim 5 \%$ at $12.1 \mathrm{ka}$, the same time as the high $\delta^{18} \mathrm{O}$ event that separates the two halves of the meltwater spike. Thus these two events correspond to the Older Dryas cold episode. Decreases in several extant coccolithophore species (Gephyrocapsa oceanica, G. [small spp.], and Umbilicosphaera sibogae) also indicate cooling in the gulf at $12.1 \mathrm{ka}$. The low percentage of reworked nannofossils suggests that meltwater flow decreased significantly during this brief glacial readvance. Flow into the gulf may not have fully recovered during the subsequent Allerød warm interval (12.1-11.3 ka), perhaps because it was partially diverted to another outlet. The negative $\delta^{18} \mathrm{O}$ anomaly during the Allerød suggests that flow was still considerable, however, as the values are too low to have been caused by warm temperatures alone. Another factor that probably contributed to the relatively low abundances of reworked nannofossils during this interval is a lack of loose, erodable sediment, because much of the sediment was likely removed in the early stages of meltwater erosion. Thus, meltwater flow into the gulf was probably substantial until $\sim 11.3 \mathrm{ka}$, when $\delta^{18} \mathrm{O}$ values increase sharply.

Evidence for mwp-IB is clearly missing from the Orca Basin sequence. This absence is contrary to the hypothesis of Broecker et al. (1989), who suggested that meltwater returned to the Gulf of
Mexico following the Younger Dryas. If major flow did return to the gulf, we would expect evidence for another high-erosion peak at $\sim 9.5 \mathrm{ka}$, as the discharge of mwp-IB was inferred by Fairbanks (1989) to be more than two-thirds that of mwp-IA. In fact, the interval between 10 and $9 \mathrm{ka}$ exhibits the lowest concentrations of reworked nannofossils in the core. There is also no negative $\delta^{18} \mathrm{O}$ anomaly (meltwater spike) during this period; the $\delta^{18} \mathrm{O}$ difference between the Younger Dryas and early Holocene $(\sim 1 \%)$ may be explained by warming and ice-volume reduction alone. The absence of mwp-IB indicates that major meltwater flow was permanently diverted away from the Gulf of Mexico at $\sim 11.3 \mathrm{ka}$. The general decrease in reworked-specimen percentages between 11.3 and $9 \mathrm{ka}$ was probably caused by rising sea levels, which covered previously exposed fan sediments and decreased the gradient of the Mississippi. Although one might argue that this sea-level rise is the reason that mwp-IB and the second half of mwp-IA do not appear in the data on percentage of reworked specimens, we see at least two reasons to disagree. First, the drop in percentage of reworked specimens at $12.1 \mathrm{ka}$ is too rapid to be explained by rising seas. Second, even with high sea levels, we would expect to see some increase in erosion centered around $9.5 \mathrm{ka}$ if mwp-IB were present. The relative constancy of $\delta^{18} \mathrm{O}$ in the pink form of Gs. ruber after $11.3 \mathrm{ka}$ offers further confirmation that major meltwater flow did not return to the gulf (Broecker et al., 1989; Flower and Kennett, 1990).

Numerous authors have shown that meltwater was diverted away from the Mississippi River at $\sim 11$ ka (e.g., Prest, 1970; Ashworth et al., 1972; Clayton and Moran, 1982; Teller and Clayton, 1983; Teller, 1985, 1987; Broecker et al., 1989). Their terrestrial evidence indicates that the retreat of the Laurentide Ice Sheet allowed meltwater passing through proglacial Lake Agassiz to flow eastward to the St. Lawrence River. These authors further argued that meltwater returned to the Mississippi at $\sim 10 \mathrm{ka}$, but this conclusion has recently been challenged. Smith and Fisher (1993) concluded that meltwater flowed from Lake Agassiz northward to the Arctic Ocean at $\sim 10 \mathrm{ka}$, rather than southward to the Gulf of Mexico. Porter and Guccione (1994) attributed the Charleston alluvial fan, the youngest product of deglacial flooding in the lower Mississippi Valley, to the pre-11 ka flow (mwp-IA). These two studies indicate that there was no major meltwater flow down the Mississippi at $\sim 10 \mathrm{ka}$, in agreement with our results. Our data are thus consistent with a diversion of meltwater to the St. Lawrence River at $\sim 11.3 \mathrm{ka}$ and a subsequent rerouting to the Arctic at $\sim 10 \mathrm{ka}$, when Lake Agassiz's eastern outlets were blocked. A meltwater trigger for the Younger Dryas cold episode, via the St. Lawrence, cannot be ruled out.

\section{CONCLUSIONS}

The abundance of reworked calcareous nannofossils in Orca Basin sediments serves as a proxy for sediment erosion into the Gulf of Mexico during the last deglaciation. Combined with oxygen isotope data from planktonic foraminifera, this proxy records the history of meltwater flow down the Mississippi River. Flow was greatest during the Bølling warm interval (12.7-12.2 ka) and remained high until the beginning of the Younger Dryas cold episode $(11.3 \mathrm{ka})$, corresponding to meltwater pulse IA. There was no return of meltwater to the Gulf of Mexico at the end of the Younger Dryas $(\sim 10$ ka), the age of meltwater pulse IB. Flow was thus permanently diverted away from the Mississippi at the beginning of the Younger Dryas cold episode.

\section{ACKNOWLEDGMENTS}

This study was begun as a part of Marchitto's senior thesis in the Department of Geology and Geophysics, Yale University; it was completed with the financial support of Republic of China National Science Council grant 
NSC-83-0102-C002-033-APM. We thank B. Flower and J. Kennett of the University of California, Santa Barbara, for providing the core samples and oxygen isotope data; W. Wei of Scripps Institution of Oceanography for assistance in identification of some reworked nannofossils; N. Tanaka of Yale University for providing sample preparation equipment; and B. Flower, L. Keigwin, J. Kennett, J. Park, M. Raymo, L. Thompson, and K. Turekian for helpful comments and criticism. Woods Hole Oceanographic Institution contribution 8915

\section{REFERENCES CITED}

Ashworth, A. C., Clayton, L., and Bickley, W. B., 1972, The Mosbeck Site: A paleoenvironmental interpretation of the Late Quaternary history of Lake Agassiz based on fossil insect and mollusc remains: Quaternary Research, v. 2, p. 176-188.

Berger, W. H., 1990, The Younger Dryas cold spell-A quest for causes: Palaeogeography, Palaeoclimatology, Palaeoecology, v. 89, p. 219-237.

Boyle, E. A., and Keigwin, L. D., 1987, North Atlantic thermohaline circulation during the past 20,000 years linked to high-latitude surface temperature: Nature, v. 330, p. 35-40.

Broecker, W. S., 1990, Salinity history of the northern Atlantic during the last deglaciation: Paleoceanography, v. 5, p. 459-467.

Broecker, W. S., Andrée, M., Wolfli, W., Oeschger, H., Bonani, G., Kennett, J., and Peteet, D., 1988, The chronology of the last deglaciation: Implications to the cause of the Younger Dryas event: Paleoceanography, v. 3, p. 1-19.

Broecker, W. S., Kennett, J. P., Flower, B. P., Teller, J. T., Trumbore, S., Bonani, G., and Wolfli, W., 1989, Routing of meltwater from the Laurentide Ice Sheet during the Younger Dryas cold episode: Nature, v. 341 , p. $318-321$.

Broecker, W. S., Bond, G., Klas, M., Bonani, G., and Wolfli, W., 1990a, A salt oscillator in the glacial Atlantic? 1. The concept: Paleoceanography, v. 5, p. 469-477.

Broecker, W. S., Klas, M., Clark, E., Trumbore, S., Bonani, G., Wolfli, W., and Ivy, S., 1990b, Accelerator mass spectrometer radiocarbon measurements on foraminifera shells from deep-sea cores: Radiocarbon, v. 32 , p. $119-133$.

Clayton, L., and Moran, S. R., 1982, Chronology of Late Wisconsinan glaciation in middle North America: Quaternary Science Reviews, v. 1, p. $55-82$.

Constans, R. E., and Parker, M. E., 1986, Calcareous nannofossil biostratigraphy and paleoclimatic indices for the Late Quaternary, Deep Sea Drilling Project Leg 96, Gulf of Mexico, in Bouma, A. H., Coleman, J. M., Meyer, A. W., et al., Initial reports of the Deep Sea Drilling Project, Volume 96: Washington, D. C., U.S. Government Printing Office, p. 601-630.

Dansgaard, W., Johnsen, S. J., Clausen, H. B., and Langway, C. C., 1971, Climatic record revealed by the Camp Century ice core, in Turekian, K. K., ed., The late Cenozoic glacial ages: New Haven, Connecticut, Yale University Press, p. 37-56.

Emiliani, C., Gartner, S., Lidz, B., Eldridge, K., Elvey, D. K., Huang, T. C., Stipp, J. J., and Swanson, M. F., 1975, Paleoclimatological analysis of Late Quaternary cores from the northeastern Gulf of Mexico: Science, v. 189 , p. $1083-1088$.

Emiliani, C., Rooth, C., and Stipp, J. J., 1978, The Late Wisconsin flood into the Gulf of Mexico: Earth and Planetary Science Letters, v. 41, p. $159-162$.

Fairbanks, R. G., 1989, A 17,000-year glacio-eustatic sea level record: Influence of glacial melting rates of the Younger Dryas event and deepocean circulation: Nature, v. 342, p. 637-642.
Flower, B. P., and Kennett, J. P., 1990, The Younger Dryas cool episode in the Gulf of Mexico: Paleoceanography, v. 5, p. 949-961.

Jansen, E., and Veum, T., 1990, Evidence for two-step deglaciation and its impact on North Atlantic deep-water circulation: Nature, v. 343, p. 612-616.

Keigwin, L. D., Jones, G. A., Lehman, S. J., and Boyle, E. A., 1991, Deglacial meltwater discharge, North Atlantic deep circulation, and abrupt climate change: Journal of Geophysical Research, v. 96, p. 16,811-16,826.

Kennett, J. P., and Shackleton, N. J., 1975, Laurentide Ice Sheet meltwater recorded in Gulf of Mexico deep-sea cores: Science, v. 188, p. 147-150.

Kennett, J. P., Elmstrom, K., and Penrose, N., 1985, The last deglaciation in Orca Basin, Gulf of Mexico: High-resolution planktonic foraminiferal changes: Palaeogeography, Palaeoclimatology, Palaeoecology, v. 50, p. 189-216.

Lehman, S. J., and Keigwin, L. D., 1992, Sudden changes in North Atlantic circulation during the last deglaciation: Nature, v. 356, p. 757-762.

Leventer, A., Williams, D. F., and Kennett, J. P., 1982, Dynamics of the Laurentide ice sheet during the last deglaciation: Evidence from the Gulf of Mexico: Earth and Planetary Science Letters, v. 59, p. 11-17.

Leventer, A., Williams, D. F., and Kennett, J. P., 1983, Relationships between anoxia, glacial meltwater and microfossil preservation in the Orca Basin, Gulf of Mexico: Marine Geology, v. 53, p. 23-40.

Porter, D. A., and Guccione, M. J., 1994, Deglacial flood origin of the Charleston alluvial fan, lower Mississippi alluvial valley: Quaternary Research, v. 41, p. 278-284.

Prest, V. K., 1970, Quaternary geology of Canada, in Douglas, R. J., ed., Geology and economic minerals of Canada: Ottawa, Geological Survey of Canada, Economic Geology Report 1, p. 677-764.

Rooth, C. G. H., 1982, Hydrology and ocean circulation: Progress in Oceanography, v. 11, p. 131-149.

Smith, D. G., and Fisher, T. G., 1993, Glacial Lake Agassiz: The northwestern outlet and paleoflood: Geology, v. 21, p. 9-12.

Teller, J. T., 1985, Glacial Lake Agassiz and its influence on the Great Lakes, in Karrow, P. F., and Calkin, P. E., eds., Quaternary evolution of the Great Lakes: Geological Association of Canada Special Paper 30 p. 1-16.

Teller, J. T., 1987, Proglacial lakes and the southern margin of the Laurentide Ice Sheet, in Ruddiman, W. F., and Wright, H. E., Jr., eds., North America and adjacent oceans during the last deglaciation: Boulder, Colorado, Geological Society of America, Geology of North America, v. K-3, p. 39-69.

Teller, J. T., and Clayton, L., eds., 1983, Glacial Lake Agassiz: Geological Association of Canada Special Paper 26, 451 p.

Veum, T., Jansen, E., Arnold, M., Beyer, I., and Duplessy, J.-C., 1992, Water mass exchange between the North Atlantic and the Norwegian Sea during the past 28,000 years: Nature, v. 356, p. $783-785$.

Manuscript received December 27, 1994

Revised manuscript received May 15, 1995

Manuscript accepted June 8, 1995 